\title{
Editorials
}

\section{Chronobiology of postoperative pain: it's time to wake up!}

Dominique Chassard MD PhD, Frédéric Duflo MD PhD, Lionel Bouvet MD, Emmanuel Boselli MD PhD

$\mathrm{P}$ AIN management remains one of the anesthesiologist's major concerns. For a considerable period of time, clinical studies have focused on the discovery of new analgesic agents, on their optimal administration modalities, and on the development of strategies that target different receptors as part of a multimodal analgesic strategy. Despite rather extensive research, there remains a subgroup of patients who remain unhappy with their treatment, whether for acute or chronic pain. The study presented by Boscariol et al. ${ }^{1}$ appearing in this issue of the Journal provides further insight into one possible explanation of this failure: the chronobiology of pain. Indeed, pain intensity is not constant on the nychthemeron. The authors observed a maximal pain peak at 8 a.m. on the morning following hysterectomy, both for static and dynamic pain. These results are all the more interesting if we consider that morphine consumption preceding this pain peak was not lower than that observed over the remainder of the first 24-hr postoperative period. Circadian variations of pain persisted even with co-analgesic agents such as non-steroidal anti-inflammatory drugs (NSAIDs) or gabapentin. This study adds a new piece to the puzzle of chronobiology in anesthesia. ${ }^{2}$

Circadian variations of response thresholds, when applying a pain stimulus, have been reported in human subjects as early as 1912. ${ }^{3}$ A reduction of response thresholds to electrical stimuli, showing pain facilitation, has been observed during the morning., ${ }^{4,5}$ However, other studies have reported a reduction of these thresholds in the evening. ${ }^{6}$ If there truly is a circadian variation of pain levels in animal as well as human subjects, then the differences are related to the various methods used: different stimuli (ther- mal, chemical or electrical), and different intensities. However, pain caused by an electrical stimulus is not as complex as postoperative pain, and the results obtained from laboratory investigations cannot be easily transposed from one field to the other. For this reason, we currently lack chronobiological data in the field of postoperative pain in a reliable animal model, which could be reproduced to confirm the clinical data from the study of Boscariol et al. ${ }^{1}$

During the day, pain is expressed in different ways depending on the disease. Migraine headaches are more frequent in the morning; biliary pain is more intense in the evening; rheumatoid arthritis pain is more intense in the morning. ${ }^{7}$ For neuropathicrelated pain, as observed in diabetics and those suffering from herpes simplex, pain intensity usually climaxes in the evening. ${ }^{8}$ Data on the diurnal variation of postoperative pain is limited and often difficult to analyze. The chronobiology of postoperative pain has been recognized, but it is often based on the analysis of postoperative morphine consumption during the waning of the postoperative phase. As is the case with chronic diseases, there is a circadian variation in the consumption of postoperative morphine that is related to the type of procedure. In Boscariol et al.'s study, morphine consumption was maximal at the beginning of the morning; these results are similar to those published by Auvil-Novak et al. ${ }^{9}$ in patients who also underwent hysterectomy. Nevertheless, it is crucial to consider further studies examining various types of surgery before asserting that all postoperative pain has a circadian variation.

During the early postoperative phase, Boscariol et al. found that pain peaks in the morning with all stimuli. The pain evaluations - with coughing, sitting, or

CAN J ANESTH 2007 / 54: 9 / pp 685-688

From the Department of Anesthesiology and Intensive Care, Hôtel-Dieu Hospital, Lyon, France.

Address correspondence to: Dr D. Chassard, Anesthesiology and Intensive Care Department, Hôtel-Dieu Hospital, 1, place de l'hôpital 69288 Lyon cedex 02, France. Phone: +33 (0) 4724131 72; Fax +33 (0) 4724131 35; E-mail: dominique.chassard@chu-lyon.fr 
forced expiration - all imply stress to the same muscle groups of the abdominal wall, thus explaining the consistency of their results. However, no previous study has been able to demonstrate a circadian variation in a neuropathological pain that can be observed postoperatively. This type of pain warrants more detailed chronobiological evaluation, because of its prevalence and the challenges it presents in treatment.

In Boscariol's study, postoperative pain peaked in the morning, even though morphine consumption had not decreased in the preceding hours. It might have been assumed that, due to their having been asleep, patients would have used less morphine during the night, but this was not the case. However, it is unclear whether the administered morphine dose was adequate, or whether the efficacy of morphine was variable on the nychthemeron. The question is difficult to answer from this study. We know that the bioavailability of oral morphine is at its maximum during the evening ${ }^{10}$ and that the maximal plasma concentrations of NSAIDs are observed in the morning or the evening depending on dosage, formulation, and time of administration. ${ }^{11}$ We therefore lack current chronopharmacological data regarding intravenous morphine and the various co-analgesic agents used postoperatively. Chronopharmacology is most certainly one research axis that could improve postoperative pain management and chronic pain. However, it is also possible that the variation in morphine efficiency is due to a cyclical variation of the number and affinity of $\mu$-receptors, a phenomenon that is much more difficult to assess.

Circadian variations in the expression of pain are probably related to circadian variations in a number of pain mediators. It is now well known that there are physiological circadian variations in the secretion of cerebral $\beta$-endorphins, of melatonin, and cortisol. ${ }^{12}$ Secretion of these mediators is more or less disrupted in the postoperative period. For example, the circadian variation of melatonin - which possesses sedative and analgesic effects - is altered with orthopedic surgery, but not after hysterectomy. ${ }^{13}$ The intensity of surgical stress and the time of day at which the surgical procedure is performed are factors to consider in future chronobiologic studies examining postoperative pain.

Continuous or regular administration of drugs cannot provide the perfect treatment of postoperative pain. The development of patient-controlled analgesia techniques has been able to meet, to a great extent, the challenges that arise from the variability of this pain. As Boscariol et al. emphasize, complimentary techniques based on pharmacological studies that explore chronobiology in the postoperative pain are warranted. Their study focusing on postoperative pain complements other studies in the field of obstetrical analgesia. ${ }^{14,15}$ Although the study group included exclusively female patients, the literature has not shown a clear circadian variation of pain related to the menstrual cycle. This point should be clarified.

Chronobiology, long ignored by our speciality, should become part of our clinical equipoise. However, further work is required in the experimental domain, and in the clinical field, there remains a need for well-designed and appropriately powered randomized controlled trials exploring chronobiological pain outcomes for various types of surgery. The authors should be congratulated for having provided further clinical evidence that many pathological or physiological phenomena, rather than being constant, are expressed in a cyclical manner. The implementation of analgesic therapies must take into account the cyclical character of pain, particularly during the postoperative phase.

\section{Chronobiologie de la douleur postopéra- toire: il est temps de se réveiller!}

La prise en charge de la douleur est une des préoccupations majeures des anesthésiologistes. De nombreuses études cliniques se sont depuis longtemps concentrées sur la recherche de nouveaux antalgiques, sur leurs modalités optimales d'administration et sur le développement de stratégies incluant plusieurs molécules différentes pour créer l'analgésie multimodale. Malgré l'ensemble de ces recherches, il persiste, que ce soit pour la douleur aiguë ou chronique, un certain nombre de patients insatisfaits de leur traitement. L'étude présentée par Boscariol et coll. ${ }^{1}$ est l'une des explications de ces échecs, la chronobiologie de la douleur. En effet, l'intensité de la douleur n'est pas constante sur le nycthémère. Ces auteurs ont observé un pic douloureux maximal à $08 \mathrm{~h} 00 \mathrm{du}$ matin dans les suites d'hystérectomies, que ce soit pour la douleur statique ou dynamique. Ces résultats sont d'autant plus intéressants que la consommation de morphine précédent ce pic douloureux n'était pas moindre que sur le reste des $24 \mathrm{~h}$. Les variations circadiennes de cette douleur per- 
sistaient même en présence de co-antalgiques comme les anti-inflammatoires non stéroïdiens (AINS) ou la gabapentine. Cette étude est une nouvelle pièce dans le puzzle de la chronobiologie en anesthésie. ${ }^{2}$

Les variations circadiennes des seuils de réponse lors d'application d'un stimulus douloureux ont été rapportées chez l'homme dès $1912 .{ }^{3}$ Une diminution des seuils de réponse à des stimuli électriques, traduisant une facilitation de la douleur, a été observée le matin. ${ }^{4,5}$ D'autres études ont cependant noté une diminution de ces seuils le soir. ${ }^{6}$ S'il existe bien une variation circadienne des seuils douloureux chez l'animal comme chez l'homme, les différences de résultats sont dues aux différentes méthodes employées : stimuli différents (thermiques, chimiques ou électriques), intensités différentes. La douleur provoquée par un stimulus électrique est cependant beaucoup moins complexe que la douleur postopératoire et les résultats obtenus sont difficilement transposables d'un domaine à l'autre. Nous manquons donc à ce jour de données chronobiologiques dans le domaine de la douleur postopératoire sur un modèle animal reproductible pour confirmer les données cliniques de cette étude.

Au cours de la journée la douleur s'exprime différemment selon les maladies. Les attaques de migraine sont plus fréquentes le matin, les douleurs biliaires plus intenses le soir, celles de la polyarthrite rhumatoïde plus intenses le matin. ${ }^{7}$ Concernant les douleurs neuropathiques observées dans le diabète ou l'herpès, elles sont maximales le soir. ${ }^{8}$ Les données concernant la douleur postopératoire sont rares et souvent difficiles à analyser. La chronobiologie de la douleur postopératoire est admise mais repose le plus souvent sur l'analyse de la consommation de morphine au décours de la phase postopératoire. Comme pour les maladies chroniques, il existe une variation circadienne de la consommation de morphine postopératoire selon le type d'intervention pratiquée. Dans l'étude de Boscariol et coll., la consommation de morphine était maximale en début de matinée, résultats proches de ceux publiés par Auvil-Novak et coll. ${ }^{9}$ chez des patientes bénéficiant aussi d'une hystérectomie. Il est cependant important de susciter de nouvelles études dans différents types de chirurgie avant d'affirmer que toutes les douleurs postopératoires ont une variation circadienne.

En phase postopératoire, l'étude de Boscariol et coll. retrouve un pic douloureux matinal quels que soient les stimuli. Les tests employés comme la toux, la position assise ou l'expiration forcée mobilisent en fait les même groupes musculaires de la paroi abdominale expliquant la concordance de ces résultats. Par contre, il n'y a pas à ce jour d'étude ayant recherché une variation circadienne concernant les douleurs neuropathiques que l'ont peut observer en phase postopératoire. Ce type de douleur mériterait une étude chronobiologique en raison de leur prévalence parfois importante et de leur traitement difficile.

La douleur postopératoire dans cette étude était maximale le matin alors que la consommation de morphine n'était pas diminuée dans les heures précédentes. On pouvait penser que du fait de leur sommeil, les patients utiliseraient moins de morphine auto-administrée, ce qui n'a pas été le cas. Malgré tout la délivrance de la morphine était-elle suffisante ou l'efficacité de la morphine est-elle variable sur le nycthémère ? Il est difficile de répondre à cette question dans cette étude. On sait cependant que la biodisponibilité de la morphine orale est maximale le soir ${ }^{10}$ et que les maximums des pics plasmatiques d'AINS sont obtenus selon les formes galéniques le soir ou le matin. ${ }^{11}$ Nous manquons donc à ce jour de données chronopharmacologiques concernant la morphine intraveineuse et les différents co-antalgiques utilisés en phase postopératoire. La chronopharmacologie est certainement un des axes de recherche pouvant améliorer la prise en charge de la douleur postopératoire et les douleurs chroniques. Cependant il se peut aussi que la variation d'efficacité de la morphine soit due à une variation cyclique du nombre et de l'affinité des récepteurs $\mu$, phénomène beaucoup plus difficile à évaluer.

Les variations circadiennes de l'expression de la douleur sont sans doute en rapport avec les variations circadiennes de nombreux médiateurs de la douleur. Il est maintenant bien connu qu'il existe physiologiquement des variations circadiennes de la sécrétion de $\beta$-endorphines cérébrales, de la mélatonine et du cortisol. ${ }^{12}$ Les sécrétions de ces médiateurs sont plus ou moins perturbées pendant la phase postopératoire. Ainsi la variation circadienne de la mélatonine qui possède des effets sédatifs et analgésiques est altérée en chirurgie orthopédique mais pas après une hystérectomie. ${ }^{13}$ L'intensité du stress chirurgical, l'heure de l'intervention chirurgicale seront des facteurs à retenir dans l'analyse des données si de futures recherches cliniques s'intéressent à cet aspect de la chronobiologie.

Une administration continue ou à horaire régulier ne peut répondre parfaitement au traitement de la douleur postopératoire. Le développement des techniques d'analgésie contrôlée par le patient a permis de répondre en grande partie à la variabilité de cette douleur. Comme le soulignent les auteurs, des techniques complémentaires sont sans doute à mettre en place, sur la base d'études pharmacologiques explorant la chronobiologie en phase postopératoire. 
Cette étude centrée sur la douleur postopératoire complète les travaux consacrés à l'analgésie obstétricale. ${ }^{14,15}$ On peut lui reprocher un collectif n'incluant que des femmes bien que la littérature n'ait pas clairement montré une variation circadienne de la douleur en fonction du cycle menstruel. Ce point mériterait d'être vérifié.

Longtemps ignorée par notre spécialité, la chronobiologie doit faire partie de notre réflexion médicale. Cependant aussi bien dans le domaine expérimental ou clinique, il manque encore des études prospectives incluant un grand nombre de patients, utilisant des méthodes d'analyses robustes et explorant différents types de chirurgie. Il faut remercier les auteurs de nous avoir une fois de plus avertis que tous les phénomènes pathologiques ou physiologiques ne sont pas constants mais s'expriment de manière cyclique. La mise en place de thérapeutiques antalgiques doit tenir compte du caractère cyclique de la douleur même en phase postopératoire.

\section{References}

1 Boscariol R, Gilron I, Orr E. Chronobiological characteristics of postoperative pain: diurnal variation of both static and dynamic pain and effects of analgesic therapy. Can J Anesth 2007; 54: 696-704.

2 Chassard D, Bruguerolle B. Chronobiology and anesthesia. Anesthesiology 2004; 100: 413-27.

3 Grabfield GP, Martin EG. Variation in the sensory threshold for faradic stimulation in normal human subjects. Am J Physiol 1912; 31: 300-8.

4 Procacci P, Corte MD, Zoppi $M$, Maresca $M$. Rhythmic changes of the cutaneous pain threshold in man. A general review. Chronobiologia 1974; 1: 77-96.

5 Bourdalle-Badie C, Andre M, Pourquier P, Robert S, Cambar J, Erny P. Circadian rhythm of pain in man: study by measure of nociceptive flexion reflex. Ann Rev Chronopharmacol 1990; 7: 249-52.

6 Frederickson RC, Burgis V, Edwards JD. Hyperalgesia induced by naloxone follows diurnal rhythm in responsivity to painful stimuli. Science 1977; 198: 756-8.

7 Rigas B, Torosis J, McDougall CJ, Vener KJ, Spiro $H M$. The circadian rhythm of biliary colic. J Clin Gastroenterol 1990; 12: 409-14.

8 Odrcich M, Bailey JM, Cabill CM, Gilvon I.

Chronobiological characteristics of painful diabetic neuropathy and postherpetic neuralgia: diurnal pain variation and effects of analgesic therapy. Pain 2006; 120: 207-12.

9 Auvil-Novak SE, Novak R, Smolensky MH, Morris MM, $K$ wan JW. Temporal variation in the self-administration of morphine sulfate via patient-controlled analgesia in postoperative gynecologic cancer patient. Ann Rev
Chronopharmacol 1990; 7: 253-6.

10 Gourlay GK, Plummer JL, Cherry DA.

Chronopharmacokinetic variability in plasma morphine concentrations following oral doses of morphine solution. Pain 1995; 61: 375-81.

11 Clench J, Reinberg A, Dziewanowska Z, Ghata J, Smolensky $M$. Circadian changes in the bioavailability and effects of indomethacin in healthy subjects. Eur J Clin Pharmacol 1981; 20: 359-69.

12 Hamra JG, Kamerling SG, Wolfsheimer KJ, Bagwell $C A$. Diurnal variation in plasma ir-beta-endorphin levels and experimental pain thresholds in the horse. Life Sci 1993; 53: 121-9.

13 Karkela J, Vakkuri O, Kaukinen S, Huang WQ Pasanen $M$. The influence of anaesthesia and surgery on the circadian rhythm of melatonin. Acta Anaesthesiol Scand 2002; 46: 30-6.

14 Debon R, Boselli E, Guyot R, Allaouchiche B, Lemmer, B. Chassard D. Chronopharmacology of intrathecal sufentanil for labor analgesia: daily variations in duration of action. Anesthesiology 2004; 101: 978-82.

15 Pan PH, Lee S, Harris L. Chronobiology of subarachnoid fentanyl for labor analgesia. Anesthesiology 2005; 103: 595-9. 